\title{
RELATIONSHIP BETWEEN STRESS COPING STRATEGIES AND ABSENTEEISM AMONG MIDDLE-LEVEL MANAGERS
}

\author{
Maja Meško* \\ Ivan Erenda ${ }^{* *}$ \\ Mateja Videmšek ${ }^{* * *}$ \\ Damir Karpljuk \\ Jože Štihec \\ Vasja Roblek
}

Received: 1. 7. 2012.

Preliminary communication

Accepted: 1. 5. 2013.

UDC: 658.3:159.942>(497.5)

The main purpose of the study is to identify the symptoms of stress, strategies for coping with stress, and absenteeism among Slovenian middle management. The survey covered 211 middle-level managers employed in large and medium-sized enterprises in Slovenia. The data was collected by using two questionnaires. The first questionnaire was used in order to determine stress coping strategies (questionnaire of coping with stress CRI). The second questionnaire was used to identify stress loads and symptoms of stress among managers. Statistical analysis was carried out using SPSS 17.0, which showed that managers who use problem-focused coping strategies are significantly less absent from work and experience lower levels of stress than managers who use emotion-focused stress coping strategies. Based on the results of the analysis, suggestions are outlined for more problem-focused approaches of stress coping strategies in Slovenian large and medium-sized enterprises.

* Maja Meško, Faculty of Management, University of Primorska, Cankarjeva 5, Koper, Slovenia, E-mail: maja.mesko@gmail.com

** Ivan Erenda, TPV d.d., Kandijska 60, 8000 Novo Mesto, E-mail: ivan.erenda@ gmail.com

*** Mateja Videmšek, Faculty of Sports, University of Ljubljana, Gortanova 22, Ljubljana, Slovenia, E-mail: mateja.videmsek@fsp.uni-lj.si

**** Damir Karpljuk, Faculty of Sports, University of Ljubljana, Gortanova 22, Ljubljana, Slovenia, E-mail: damir.karpljuk@fsp.uni-lj.si

***** Jože Štihec, Faculty of Sports, University of Ljubljana, Gortanova 22, Ljubljana, Slovenia, E-mail: joze.stihec@fsp.uni-lj.si

****** Vasja Roblek (Corresponding author), independent researcher, Pot na Zali rovt 16, 4290 Tržič, Slovenia, E-mail: vasja.roblek@gmail.com 
Management, Vol. 18, 2013, 1, pp. 45-57

M. Meško et al.: Relationship between stress coping strategies and absenteeism among...

\section{INTRODUCTION}

Stress is frequently considered as the most common disease of the modern age. It is a pattern of negative physiological states and psychological responses that occur in an individual. When stressed, an individual feels that his well-being is menaced but is at the same time unable to cope with it (Lazarus and Folkman, 1984; Hill, 2001). Stress has implications for both the individual and the organization. In individuals, it has a negative impact on work performance, resulting in decreased motivation and constant fatigue (Armstrong, 2009). In organizations, it has an effect on an organizational bottom line as numerous working days are lost due to stress consequences (Perimäki - Dietrich, 2002).

In the workplace, stress occurs when employees try to cope with the duties, responsibilities and other forms of pressure associated with their jobs, but encounter difficulties, anxiety and worries in trying to manage them (Stranks, 2005). Work stress is a mental state that can cause behavioural disorders in individuals (Looker and Gregson, 1994). It is a result of the imbalance between job requirements and the ability to cope. Work stress, with all its consequences, is widely spread in the EU member states. According to various studies, managers in the acceding EU member states are exposed to stress and are more overloaded with work than their Western counterparts (Singh and Dube, 2011).

Work stress is a typical phenomenon for middle-level managers. In the case of middle managers, work stress is usually associated with too much or too little work, conflicting job demands, incompetent superiors, excessive hours of work, and the conflict between work and family responsibilities (Mathis and Jackson, 2004). Employers are obliged to limit and suppress stress by striving to prevent stress in their organizations, assessing risks for stress appearance and through this process reveal the stress risks at the workplace. Sutherland and Cooper (2009) argue that strategies for reducing and eliminating stress in the workplace depend on a precise definition of risk factors, appropriately chosen stress coping strategies among employees, and supervision and control over the introduction of changes.

\section{STRESS COPING STRATEGIES}

In most cases, the causes of stress cannot be prevented, but we can overcome the consequences by using appropriate strategies for coping with stress. People cope with stressful situations in different ways. In our research we focused on stress coping strategies defined by Moos (1992), who divided stress coping strategies into problem-focused and emotion-focused. For the purpose of the study, we used the 
"Coping Response Inventory" to determine the stress-coping strategies of Slovenian middle-level managers. The coping style is assessed using eight CRI sub-scales. Logical analysis (LA) measures the cognitive effort to understand the stressor and the attempt to mentally prepare for the stressor and its consequences. Positive appraisal (PA) involves an effort to explain and positively reinterpret the problem while at the same time accepting the reality of the situation. Seeking guidance or support (SS) consists of behavioural efforts to seek information, guidance and support. Problem-solving action (PS) includes behavioural efforts to do something and to deal with a problem directly. Cognitive avoidance (CA) measures cognitive efforts to avoid realistic consideration of the problem. Acceptance or resignation (A) encompasses cognitive efforts to respond to a problem by accepting it. Seeking alternative rewards (AR) includes behavioural efforts to engage in new activities and create new sources of satisfaction. Emotional discharge or emptying (ED) covers behavioural efforts to alleviate tension by venting negative emotions. The first four strategies constitute the strategies of approaching (problem-focused) and the last four the strategies of avoidance (emotion-focused). The strategies are further divided into cognitive and behavioural (Moos, 1992).

The results of the studies on stress-coping strategies show that individuals cope with stress more effectively when they are facing a problem or when their coping strategy focuses on a problem and requires their action (Dillinger et al., 2003). We propose that problem-focused stress coping strategies cause less absenteeism in organizations.

\section{ABSENTEEISM AND STRESS}

Absenteeism is a temporary absence from work (temporary withdrawal from the organization) for reasons such as illness, death in the family or other personal reasons (Mathis and Jackson, 2004). The reasons for absenteeism are either (e.g. Armstrong, 2009; Mathis and Jackson, 2004; Torrington et al., 2005):

- mainly objective in nature (and therefore harder to influence);

- predominantly subjective (psychological reasons such as the occurrence of stress and, consequently, cardiovascular diseases, or social reasons such as stimulant dependency, anorexia and insomnia, poor concentration, etc.).

Absenteeism poses a problem for organizations, because of negative consequences such as direct compensation costs, replacement costs, lower productivity costs, etc. (Mathis and Jackson, 2004). European surveys have shown that workplace absenteeism is accompanied by concurrent increases in work-related 
Management, Vol. 18, 2013, 1, pp. 45-57

M. Meško et al.: Relationship between stress coping strategies and absenteeism among...

stress (Borg et al., 2000). In fact, rates of absenteeism have become a global standard by which workers' health is measured (Kivimäki et al., 2003).

\subsection{Absenteeism in Slovenia}

The Health Insurance Institute of Slovenia (HII)'s survey has shown the main causes of absenteeism in Slovenia are: caring for the immediate family members, personal illness, and injuries sustained outside the workplace. Temporary absence from work places the burden on employers while both the number of cases as well as the number of working days lost by far the forefront of disease and injury outside of work (Vučković, 2010).

The mean length of sick leave in Slovenia (for a total burden borne by employers and the HII) was 12.1 days in 2008 and 11.7 days in 2009 (Vučković, 2010). By contrast, the mean length of sick leave in the EU-27 countries is 4.5 days. The problem of absenteeism in Slovenian organizations has a profound impact on labour costs and production (Svetlik, 2009).

\subsection{Prevention of absenteeism}

Organizations should create a friendly working environment, enable employees to work from home or outside ordinary working hours, divide work between fulltime employees, reduce statutory working hours, etc. - see Table 1 (Torrington, 2005).

Furthermore, some of the most important measures which could have a strong impact on the absenteeism rates among middle-level managers are:

- Measures for health and safety at work, employers' responsibility for one's health;

- Working environment, increased worker motivation and stimulation for the rarer absenteeism and faster return to work, the level of social security, which in certain cases can encourage absenteeism, the relevant legislation, which would not permit the abuse of the rights of the individuals, the attitude of health services toward absences from work, etc.

The main aim of the study was to establish the stress-coping techniques of Slovenian managers and to establish the relationship between stress-coping strategies and stress level and absenteeism among middle-level managers. 
Table 1: Causes and occurrence of absenteeism

\begin{tabular}{|c|l|}
\hline $\begin{array}{c}\text { THE REASONS } \\
\text { FOR THE } \\
\text { OCCURRENCE OF } \\
\text { ABSENTEEISM }\end{array}$ & \multicolumn{1}{|c|}{ FACTORS FOR REDUCING ABSENTEEISM AND } \\
CONSEQUENT STRESS
\end{tabular}

Source: Armstrong, 2009; Mathis and Jackson, 2004; Torrington et al. 2005. 
Management, Vol. 18, 2013, 1, pp. 45-57

M. Meško et al.: Relationship between stress coping strategies and absenteeism among...

Two hypotheses were proposed:

- Hypothesis 1. Managers who use problem-focused stress coping strategies are absent from work significantly less often than managers who use emotion-focused coping strategies.

- Hypothesis 2. Managers who use problem-focused coping strategies experience significantly lower levels of stress in the workplace than managers who use emotion-focused coping strategies.

\section{METHODOLOGY}

\subsection{Sample}

The sample included 211 middle-level managers, which are representative of the total number of middle-level managers employed in large and medium-sized enterprises in Slovenia. We chose middle-level managers because they were frequently caught between their employees' needs and demands and the demands of their superiors, i.e. the top management.

The responsibilities of middle-level managers include taking care of production programs, seeing that the company's goals and targets are achieved, assuming risks, reaching decisions and being flexible with regard to changes. They must make decisions concerned not only with the future of the organization as a system, but also with personnel management and the organization's information system.

The study included 97 female and 114 male managers. The largest group consisted of middle-level managers aged between 31 and 40 years $(49.4 \%)$, followed by 41-50 year-old managers (34.1\%), and managers younger than 30 $(16.5 \%)$. The highest share was accounted for by highly-educated managers $(92.9 \%$ of all). Finally, $41.2 \%$ of the managers that participated in the study belonged to a group whose years of service ranged between 11 and 20 years, $27.1 \%$ had 6-10 years of service, whereas the rest either had more than 20 or less than 6 years of service.

\subsection{Research instruments}

The survey was carried out using two questionnaires. The first questionnaire was used to determine what strategies managers use to cope with stress (questionnaire of coping with stress CRI). The questionnaire consists of two parts. The introductory part (10 items), where respondents present a major problem from the previous year of their life, is followed by a longer second part (48 items) where 
the coping style is assessed using eight CRI sub-scales: logical analysis (LA), positive appraisal (PA), seeking guidance or support (SS), and problem-solving action (PS) on the one hand (thus assessing problem-focused coping styles) and cognitive avoidance (CA), acceptance or resignation (A), seeking alternative rewards (AR) and emotional discharge or emptying (ED) (thus assessing coping styles focused away from the problem) on the other hand. Each scale consists of six items, while the entire inventory consists of 48 items.

Respondents react to items by indicating on a four-level scale (from 'never' to 'very frequently') how often they used individual strategies. The minimum score of each dimension was 0 and the maximum score was 18 . The authors of the Slovenian translation of the CRI are Masten, Tušak and Ziherl, who were the first to apply this instrument to the Slovenian population (frame norms exist). The reliability of the instrument was adequate. The established degree of constructive validity was also adequate (Moos, 1992).

The second questionnaire was used to identify stress loads and symptoms of stress among managers. The general part of the first questionnaire included demographic questions about the respondents (gender, age, education level, work experience, job), while the second part dealt with hypotheses. The questionnaire consists of the following:

- Issues related to the subjective evaluation of the degree of stress;

- A list of symptoms of stress consisting of 48 feelings and conditions which are likely to occur as a result of stress (Braham, 1994; Černelič, 1999; Luban - Plozza and Pozzi, 1994; Powell, 1999). Middle-level managers graded the symptoms on a 5-point Likert scale depending on the frequency of their occurrence, where 1 represented 'never' and 5 represented 'very often';

- Questions on absenteeism (the number of days missed from work due to symptoms of stress in the period of one year, the duration of one absence, the number of separate periods of absence).

\subsection{Data processing}

The data was then analysed with SPSS for Windows 17.0. The following statistical methods were used: descriptive statistics and frequency distribution and ANOVA (to examine the statistical relevance of the differences between groups). The statistically relevant conclusions were drawn at a $95 \%$ confidence interval. 
Management, Vol. 18, 2013, 1, pp. 45-57

M. Meško et al.: Relationship between stress coping strategies and absenteeism among...

\section{RESULTS}

The aim of our study was to find out whether the use of problem-focused coping strategies and experienced stress level are connected with absenteeism and stress level among middle-level managers. Work-related stress was graded on a scale from 1 to 5 , where 1 stood for 'completely undisturbing', 2 'slightly disturbing', 3 'moderately disturbing', 4 'very disturbing', and 5 'extremely disturbing'. The mean score was 2.68 for women and 2.38 for men, which shows that women find work-related stress more disturbing than men. For the purpose of examining hypotheses 1 and 2, we used the common variables 'strat_problem' and 'strat_feelings'. Values from 0 to 20 were given a value of 1 (low strategy use), values from 21 to 40 were given a value of 2 (medium strategy use), and values from 41 to 72 were given a value of 3 (high strategy use).

To test Hypotheses 1 and 2, we used one-way analysis of variance (Oneway ANOVA), with which we could check the feature of differences between the averages in the population in several groups. In our case, we examined the differences between respondents with low, medium or high levels of use of coping strategies.

With the one-way analysis of variance, we tested the assumption on the differences in the frequency of absences from work according to strategies used to cope with stress. The frequency of absence from work was measured with a 5-point scale, where 1 corresponded to ' 0 to 5 days of absence' and 5 corresponded to ' 21 or more days of absence'. Table 2 shows the mean absenteeism scores of groups that use problem-focused coping strategies or emotion-focused coping strategies.

Table 2. Mean scores for: 'How many days were you absent from work due to illness?' (One-way analysis of variance)

\begin{tabular}{|c|c|c|c|c|}
\hline \multirow{2}{*}{$\begin{array}{c}\text { Level of } \\
\text { absenteeism }\end{array}$} & \multicolumn{2}{|c|}{ Problem-focused strategies } & \multicolumn{2}{c|}{ Emotion-focused strategies } \\
\cline { 2 - 5 } & M & SD & M & SD \\
\hline $\begin{array}{c}\text { Low level of } \\
\text { absenteeism }\end{array}$ & 2.25 & 0.622 & 1.50 & 0.906 \\
\hline $\begin{array}{c}\text { Medium level of } \\
\text { absenteeism }\end{array}$ & 1.85 & 0.904 & 1.42 & 0.928 \\
\hline $\begin{array}{c}\text { High level of } \\
\text { absenteeism }\end{array}$ & 1.54 & 1.036 & 2.71 & 1.254 \\
\hline & \multicolumn{2}{|c|}{$\begin{array}{c}\text { F statistics } \mathbf{3 . 2 3 9} \\
\text { sig. } \mathbf{0 . 0 2 4}\end{array}$} & $\begin{array}{c}\text { F statistics }=\mathbf{2 . 8 6 4} \\
\text { sig. } \mathbf{0 . 0 3 9}\end{array}$ \\
\hline
\end{tabular}


The hypothesis that managers who use problem-focused coping strategies are absent from work significantly less often than managers who use coping emotionfocused strategies can be confirmed.

The assumption of the differences in the assessment of stress in the workplace according to the strategy used to cope with stress was tested with the one-way analysis of variance. The rate of workplace stress was measured by a 5-point scale, where 1 means that respondents perceive their work as being completely stress-free, and 5 that they perceive it as being extremely stressful.

Table 3 shows the mean estimates of stress in the workplace according to the degree of use of problem-focused coping strategies or emotion-focused coping strategies.

Table 3. Mean scores for: 'How stressful do you find your job?' (One-way analysis of variance)

\begin{tabular}{|c|c|c|c|c|}
\hline $\begin{array}{c}\text { Level of } \\
\text { absenteeism }\end{array}$ & \multicolumn{2}{|c|}{ Problem-focused strategies } & \multicolumn{2}{|c|}{ Emotion-focused strategies } \\
\cline { 2 - 5 } & M & SD & M & SD \\
\hline $\begin{array}{c}\text { Lowsenteeism } \\
\text { Medium level of } \\
\text { absenteeism }\end{array}$ & 3.15 & 0.562 & 1.50 & 0.876 \\
\hline $\begin{array}{c}\text { High level of } \\
\text { absenteeism }\end{array}$ & 1.54 & 1.136 & 2.81 & 1.134 \\
\hline \multicolumn{2}{|c|}{$\begin{array}{c}\text { F statistics }=\mathbf{4 . 4 1 0} \\
\text { sig. }=\mathbf{0 . 0 6 5}\end{array}$} & $\begin{array}{c}\text { F statistics = 3.566; } \\
\text { sig. = 0.016 }\end{array}$ \\
\hline
\end{tabular}

The hypothesis that managers who use problem-focused coping strategies experience significantly lower levels of stress in the workplace than managers who use emotion-focused coping strategies can be confirmed. In terms of stress symptom frequency, we found out the following the most frequent items or symptoms among middle-level managers: fatigue and lack of energy $(\mathrm{M}=3.47)$, high use of caffeine and nicotine ( $M=3.28)$, moodiness $(M=3.17)$, anxiety $(M=3.0)$, desire to quit the job $(M=2.96)$, forgetfulness $(M=2.56)$, concentration problems $(\mathrm{M}=2.53)$, and frequent use of tranquillizers $(\mathrm{M}=2.51)$.

\section{DISCUSSION AND CONCLUSION}

Cooper and Marshall (1978) identify an 'organizational boundary', with the individual manager straddling that boundary and, in effect, endeavouring to cope 
with conflicting stressors created by external (the family) and internal (the organization) demands. Too much stress among managers leads to poor health and higher rates of absenteeism. Peoples' lives normally require a certain amount of stress; therefore not all stress is negative. Most people require a certain amount of pressure to efficiently complete tasks. The occurrence of certain level of stress is associated with effective management. Managers enable their subordinates with whom they cooperate. They provide them with active support and evaluate their efforts. This kind of stress has a positive impact on managers' satisfaction and overall effectiveness (Skakon et al., 2011).

Problems arise when there is too much of stress, and when it becomes too intense or is prolonged. Excessive and repeated exposure to stress is linked with diseases such as cardiovascular disease, skin disease, gastrointestinal disease, and cancer (Lazarus and Folkman, 1984). When there is too much stress, it is important to use appropriate stress reduction strategies. Then, the organizations should follow a specific course of action as well. First, it is essential to identify which work factors cause stress. Stress factors can be identified by distributing questionnaires to employees, holding individual interviews, and reviewing work processes and absenteeism rates due to illness (Mathis and Jackson 2004). Then, changes in the micro-environment including improving work morale, motivation, and performance should be made. It is necessary to introduce communication exercises (e.g. communication between applications, negotiations, etc.) and to teach employees how to deal with stress.

In our study, we focused on stress detection among middle managers employed in large and medium-sized enterprises in Slovenia and the impact of stress coping strategies on stress level and absenteeism. Managerial positions typically involve a heavy workload. Managers who participated in our survey described their work as stressful. To cope with stress, they mostly use problem-focused strategies.

In our research, we proved that problem-focused approaches were less frequently used among managers who experience fewer stress symptoms and stress loads than among managers who use non-problem-focused approaches. The main finding shows that the managers that use problem-focused stress coping strategies are absent from work significantly less often and experience significantly lower levels of stress in the workplace than managers who use emotion-focused coping strategies.

Based on this finding, we provided suggestions for middle-size and large organizations to develop more efficient stress management. Therefore, we can 
suggest that organizations provide a training of appropriate stress coping strategies (a stress management program). We assumed that more stress coping training would decrease the absenteeism rates caused by stress and the experience of stress level among middle-level managers would also decrease. The outcomes of our research can have an influence on a greater efficiency of managing stress in organizations. With the suggested improvements we identified the areas that are lacking in stress management.

Our study was limited to stress detection and stress coping strategies, and its impact on absenteeism among middle managers in medium-sized and large Slovenian enterprises. We believe that extensive research on the influence of stress factors on absenteeism should be done in public organizations, such as enterprises at the national level. The study should cover all employees and not just individual groups. Such a study would provide a realistic picture of the occurrence of stress and its impact on absenteeism on the national level. The study would be of great help to enterprises that lack sufficient resources to conduct their own research into stress in order to develop action plans for its elimination. We suggest that further research be based on a larger number of subjects and include other instruments for measuring stress-coping strategies. The further researches should also focus on small enterprises and micro-businesses.

\section{REFERENCES}

1. Armstrong, M. (2009.) Armstrong's handbook of human resource management practice. London: Kogan Page.

2. Borg, V., Brouwers, A., Kuhn, K., Neboit, M., Méreau, P., Nogareda, S. (2000.) Research on Work-related Stress. Luxembourg: Office for Official Publications of the European Communities (European Agency for Safety and Health at Work).

3. Braham, B. J. (1994.) Managing stress: keeping calm under fire. Irwin Professional Publishing, Burr Ridge, New York.

4. Cooper, C. L., Marshall, J. (1978.) Occupational sources of stress. A review of the literature relating to coronary heart disease and mental ill-health. Journal of Occupational Psychology, 49, pp. 11-28.

5. Černelič, M. (1999.) Izvori stresa. Primorska srečanja, 23 (219-220), pp. 573576.

6. Dillinger, T. G., Wiegmann D. A., Taneja, N. (2003.) Relating personality with stress coping strategies among student pilots in a collegiate flight training program. In R.S. Jensen (Ed.). Proceedings of the 12th International Symposium on Aviation Psychology. Dayton, OH: The Ohio State University. 
Management, Vol. 18, 2013, 1, pp. 45-57

M. Meško et al.: Relationship between stress coping strategies and absenteeism among...

7. Hill, G. (2011.) Psihologija: shematski prikaz. Ljubljana: Tehniška založba Slovenije.

8. Kivimäki, M., Head, J., Ferrie, J. E., Shipley, M. J., Vahtera, J., Marmot, M. G. (2003.) Sickness absence as a global measure of health: evidence from mortality in the Whitehall II prospective cohort study. British Medical Journal, 327 (7411), pp. 364-384.

9. Lazarus S. R., Folkman S. (1984.) Stress, appraisal, and coping. New York: Springer Publishing Company.

10. Looker, T., Gregson, O. (1993.) Obvladajmo stres: kaj lahko z razumom naredimo proti stresu. Ljubljana: Cankarjeva založba.

11. Luban-Plozza, B., Pozzi, U. (1994.) V sožitju s stresom. Državna založba Slovenije, Ljubljana.

12. Mathis, R. L., Jackson, H. J. (2004.) Human resource management. Mason: Thomson/South-Western.

13. Moos, R. H. (1992.) Coping responses inventory manual, In Milne, D. L. (Ed.). Assessment: A Mental Health Portfolio. NFER Nelson, Windsor.

14. Perimäki-Dietrich, R. (2002.) Stress gemeinsam bekämpfen (Stress lass nach! Bewusster Umgang mit Stress). Magazine der Europäische Agentur für Sicherheit und Gesundheitsschutz am Arbeitsplatz, 5, https://osha.europa.eu/de/publications/magazine/5, pp. 14-15.

15. Powell, T., 1999. Kako premagamo stres. Ljubljana: Mladinska knjiga.

16. Singh, P. A., Dubey, K. A. (2011.) Role of stress and locus of control in job satisfaction among middle managers. Journal of Organizational Behaviour, 10(1), pp. 42-56.

17. Skakon, J., Kristensen, S. T., Christensen, B. K., Lund, T., Labriola, M. (2011.) Do managers experience more stress than employees? Results from the intervention project on absence and well-being (IPAW) study among Danish managers and their employees. Work: A Journal of Prevention, Assessment and Rehabilitation, 38 (29), pp. 103-109.

18. Sutherland, V., Cooper, C. (2009.) Strategic stress management. Houndmills: Macmillan.

19. Stranks, J. (2005.) Stress at work: Management and prevention. Burlington: Elsevier Butterworth - Heinemann.

20. Svetlik, I. (2009.) Oblikovanje dela in kakovost delovnega življenja. In Svetlik, I., Zupan, N. (Eds.), Menedžment človeških virov, (pp. 339-381). Ljubljana: Fakulteta za družbene vede.

21. Torrington, D., Hall, L., Taylor, S. (2005.) Human resource management. Harlow: Pearson Education.

22. Vučković, R. (2010.) Obvladovanje zdravstvenega absentizma - izziv za družbo. In Kos, D. (Ed), Zdravstveni absentizem v Sloveniji: zbornik primerov 
Management, Vol. 18, 2013, 1, pp. 45-57

M. Meško et al.: Relationship between stress coping strategies and absenteeism among...

iz prakse 14 slovenskih podjetjih, (pp. 10-20). Ljubljana: Zavod za zdravstveno zavarovanje Slovenije.

\title{
ODNOS IZMEĐU STRATEGIJA UPRAVLJANJA STRESOM I APSENTIZMA MEĐU MENADŽERIMA SREDNJE RAZINE
}

\begin{abstract}
Sažetak
Temeljni cilj ovog rada je utvrđivanje simptoma stresa, strategija za upravljanje stresom te apsentizma slovenskih menadžera srednje razine. Istraživanjem je obuhvaćeno 211 menadžera srednje razine, zaposlenih u velikim i srednjim slovenskim poduzećima. Podaci su prikupljeni uz pomoć dva upitnika. Prvi se upitnik koristio za utvrđivanje strategije za upravljanje stresom (upitnik CRI), dok se drugi koristio za utvrđivanje razine i simptoma stresa među menadžerima. Statistička je analiza provedena uz pomoć softverskog paketa SPSS for Windows 17.0. Pritom se pokazalo da menadžeri, koji koriste strategije upravljanja stresom usmjerene na probleme, imaju manju razinu stresa i manju razinu apsentizma u odnosu na menadžere, koji koriste strategije usmjerene na emocije. Na temelju rezultata analize, predlaže se primjena problemski usmjerenih strategija upravljanja stresom u velikim i srednjim slovenskim poduzećima.
\end{abstract}



